\title{
Astaxanthin protects astrocytes against trauma-induced apoptosis through inhibition of NKCC1 expression via the NF-kB signaling pathway
}

\author{
Mingkun Zhang ${ }^{1,2 \dagger}$, Zhenwen Cui ${ }^{2,3 \dagger}$, Hua Cui ${ }^{1}$, Yong Wang ${ }^{1 *}$ and Chunlong Zhong ${ }^{2^{*}}$ (D)
}

\begin{abstract}
Background: Astaxanthin (ATX) is a carotenoid pigment with pleiotropic pharmacological properties that is seen as a possible drug for treating cerebral ischemic injury and subarachnoid hemorrhage. $\mathrm{Na}^{+}-\mathrm{K}^{+}-2 \mathrm{Cl}^{-} \mathrm{co}-$ transporter-1 (NKCC1), an intrinsic membrane protein expressed by many cell types, is activated by various insults, leading to the formation of cell swelling and brain edema. We previously established that ATX attenuated brain edema and improved neurological outcomes by modulating NKCC1 expression after traumatic brain injury in mice. This paper explored the molecular mechanism of ATX-mediated inhibition of NKCC1 utilizing an in vitro astrocyte stretch injury model.

Results: Stretch injury in cultured astrocytes lowered cell viability time-dependently, which was substantially reducing by pretreating with ATX (50 $\mathrm{mol} / \mathrm{L})$. Stretch injury increased Bax level and cleaved caspase-3 activity, and decreased $\mathrm{BCl}-2$ level and pro-caspase 3 activity, resulting in the apoptosis of astrocytes. Additionally, stretch injury substantially raised the gene and protein expressions of interleukin (IL)-1 $\beta$, IL-6, and tumor necrosis factor (TNF)- $a$ and prompted the expression and nuclear translocation of NF-KB. Pretreatment with ATX remarkably prevented the trauma-induced initiation of NF-kB, expressions of pro-inflammatory cytokines, and cell apoptosis. Moreover, stretch injury markedly elevated the gene and protein expression of NKCC1, which was partly blocked by co-treatment with ATX (50 $\mu \mathrm{mol} / \mathrm{L}$ ) or an NF-KB inhibitor (PDTC, $10 \mu \mathrm{mol} / \mathrm{L})$. Cleaved caspase-3 activity was partially reduced by PDTC $(10 \mu \mathrm{mol} / \mathrm{L})$ or an NKCC1 inhibitor (bumetanide, $50 \mu \mathrm{mol} / \mathrm{L})$.
\end{abstract}

Conclusions: ATX attenuates apoptosis after stretch injury in cultured astrocytes by inhibiting NKCC1 expression, and it acts by reducing the expression of NF-KB-mediated pro-inflammatory factors.

Keywords: Astaxanthin, Traumatic brain injury, Apoptosis, Astrocyte, $\mathrm{Na}^{+}-\mathrm{K}^{+}-2 \mathrm{Cl}^{-}$cO-transporter-1, NF- $\mathrm{KB}$

\section{Background}

Cerebral edema is secondary to primary lesions or dysfunction of the nervous system after traumatic brain injury (TBI). One outcome of edema is the development

\footnotetext{
*Correspondence: drchunlongzhong@126.com; wangyong68@163.com ${ }^{\dagger}$ Mingkun Zhang and Zhenwen Cui contributed equally to this work

1 Department of Neurosurgery, Ren Ji Hospital, School of Medicine, Shanghai Jiao Tong University, Shanghai 200127, China

${ }^{2}$ Department of Neurosurgery, East Hospital, Tongji University School of Medicine, 150 Jimo Road, Shanghai 200120, China

Full list of author information is available at the end of the article
}

of increased intracranial pressure, which can result in brainstem compression, brain herniation, coma, and failure of the respiratory and/or cardiovascular systems [1]. Edema, as well as the complications associated with it, is responsible for up to $50 \%$ of the mortality in all victims of TBI [2]. Despite the fact that vasogenic as well as cytotoxic mechanisms participate in TBI-related brain edema, cytotoxic edema (intracellular swelling) prevails in the early phase (2-24 h) of TBI, at which point astrocytes are the major cell type affected [3]. Although it has been documented over the course of several years as a 
critical post-TBI issue, cerebral edema treatment strategies are currently limited, and a majority of them are not effective.

Astaxanthin (ATX), a lipophilic compound extracted from crustaceans, algae, shellfish, and a variety of plants [4], has strong biological effects, including antioxidative, anti-inflammatory, antitumor, and immunomodulatory activities $[5,6]$. Recently, studies have shown that the antioxidant and anti-inflammatory effects of ATX are beneficial for the treatment of central nervous system diseases without causing any side effects or toxicity [7-10]. Treatment with ATX after subarachnoid hemorrhage significantly downregulated increased nuclear factor kappa B (NF-KB) activity and the expression of inflammatory cytokines via messenger RNA transcription and protein synthesis, leading to the amelioration of blood-brain barrier disruption, cerebral edema, neuronal degeneration, and neurological dysfunction [8]. We previously reported that ATX attenuated brain edema and improved neurological outcomes in TBI mice [11]. Yet, the molecular mechanisms underlying the ATX-dependent inhibition of the cerebral edema in TBI remain poorly understood.

The $\mathrm{Na}^{+}-\mathrm{K}^{+}-2 \mathrm{Cl}^{-}$co-transporter-1 (NKCC1) is an intrinsic membrane protein expressed in a plethora of cell types, including astrocytes, cortical and cerebellar neurons, oligodendrocytes, brain capillary endothelial cells, and epithelial cells of the choroid plexus [12, 13]. It plays a vital part in cell volume homeostasis by transporting chloride, sodium and/or potassium ions, across the plasma membranes of cells. The inappropriate activation of NKCC1 is implicated in the formation of cell swelling and brain edema caused by various insults, including TBI [12, 14-16], ischemic stroke [17-19], hemorrhagic stroke [13], and tumors [20, 21]. Edema was markedly reduced by the cotransporter inhibitor bumetanide or genetic deficiency [13]. The goal of this study was to elucidate whether the neuroprotective effects of ATX are associated with alterations of NKCC1 levels using an in vitro astrocyte stretch injury model. Furthermore, we determined whether ATX administration decreased NKCC1 expression to clarify the possible regulatory pathway.

\section{Methods}

\section{Materials}

ATX (Santa Cruz Biotechnology, Santa Cruz, CA, USA, 98\% pure) was dissolved in dimethyl sulfoxide (DMSO); the DMSO content in every group was $0.1 \%$. Pyrrolidine dithiocarbamate (PDTC), a NF-кB inhibitor, was purchased from Beyotime (Jiangsu, China) and used at a concentration of $10 \mu \mathrm{mol} / \mathrm{L}$. Bumetanide, a NKCC1specific inhibitor, was purchased from Sigma-Aldrich (St. Louis, MO, USA) and used at a concentration of
$50 \mu \mathrm{mol} / \mathrm{L}$ [22]. Anti-NKCC1, anti-glial fibrillary acidic protein (GFAP) and anti-NF- $\mathrm{KB} / \mathrm{p} 65$ antibodies were purchased from Millipore (Billerica, MA, USA) and Santa Cruz Biotechnology, respectively. Anti-pro caspase 3 antibody was purchased from Abcam (Cambridge, MA, USA). Antibodies against Bcl-2, Bax, cleaved caspase-3, IL-1 $\beta$, IL-6, TNF- $\alpha, \beta$-actin, $\beta$-tubulin, and Histone H3 were purchased from Cell Signaling Technology (Danvers, MA, USA).

\section{Astroglial cell culture}

All experimental protocols were performed in accordance with the guidelines of the Institutional Ethics Committee of Renji Hospital, Shanghai Jiao Tong University School of Medicine. Primary cultures of astrocytes were isolated from the cerebral cortices of neonatal C57BL/6 mouse pups (P0-P3). After the meninges and blood vessels were carefully removed under a dissecting microscope, cerebral tissues were minced mechanically and incubated in $0.25 \%$ trypsin for $10 \mathrm{~min}$. Isolated cells were grown until confluent in astrocyte medium [Dulbecco's modified Eagle's medium supplemented with $4.5 \mathrm{~g} / \mathrm{L} \mathrm{D}$-glucose, $4 \mathrm{mmol} / \mathrm{L}$ L-glutamine, $3.7 \mathrm{~g} / \mathrm{L}$ sodium bicarbonate, with $10 \%$ fetal bovine serum, penicillin (100 units $/ \mathrm{ml})$ and streptomycin $(100 \mathrm{mg} / \mathrm{ml})]$. Greater than $90 \%$ of cells in these cultures were GFAP-positive. The cells were maintained in a humidified atmosphere at $37{ }^{\circ} \mathrm{C}$ with $95 \%$ air $-5 \% \mathrm{CO}_{2}$. The culture medium was renewed after $24 \mathrm{~h}$, and then every 2 days thereafter.

\section{Cell injury}

After 7-to-10 days, confluent cultures of astrocytes grown in BioFlex ${ }^{\circledR}$ Plates were injured using a model 94A Cell Injury Controller [23]. Briefly, a 50-ms pulse of compressed air was used to rapidly deform the Silastic membrane of adherent astrocytes to produce a $7.5-\mathrm{mm}$ membrane deflection, which corresponds to a $54 \%$ membrane stretch and severe cell injury. After the insult, cells were placed in a $95-5 \%$ air $-\mathrm{CO}_{2}$ incubator at $37{ }^{\circ} \mathrm{C}$ for various times. The cells in the ATX-treated group were incubated with ATX for $2 \mathrm{~h}$ before injury and for an additional $24 \mathrm{~h}$ without altering the culture medium. Cells treated with PDTC or bumetanide were performed identically. The control-cultured cells were incubated over $24 \mathrm{~h}$ with culture medium. It is important to note that no hypoxic or ischemic conditions were imposed on the injured cells in these experiments.

\section{Cell viability assay}

A Cell Counting Kit-8 (CCK-8, Beyotime Biotechnology, Jiangsu, China) was used to quantitatively evaluate cell viability according to the manufacturer's instructions. In short, $90 \mathrm{ml}$ of cell suspension was incubated along with 
$10 \mathrm{ml}$ of 2-(2-methoxy-4-nitrophenyl)-3-(4-nitrophenyl)5-(2,4-disulfophenyl)-2 $\mathrm{H}$-tetrazolium and monosodium salt (WST-8) solution for $4 \mathrm{~h}$ at $37^{\circ} \mathrm{C}$ in a $5 \% \mathrm{CO}_{2}$ atmosphere before terminating the assay. The optical density (OD) values were measured at $450 \mathrm{~nm}$ using a microplate reader (680; Bio-Rad, Hercules, CA, USA).

\section{In situ cell death detection}

Apoptotic cells were investigated by TdT-dUTP nick-end labeling (TUNEL) assays with a one-step in situ cell death detection kit (Roche, Germany) based on the manufacturer's directions. After injury, astrocytes were fixed with freshly prepared $4 \%$ paraformaldehyde solution in phosphate buffered saline (PBS) for $60 \mathrm{~min}$ at $4{ }^{\circ} \mathrm{C}$, washed with fresh PBS twice for $5 \mathrm{~min}$, and then incubated with $0.1 \%$ Triton X-100 for $2 \mathrm{~min}$ on ice. The cells were then incubated with $50 \mu \mathrm{l}$ of TUNEL reaction mixture in a humidified atmosphere for $1 \mathrm{~h}$ at $37{ }^{\circ} \mathrm{C}$ in the dark, and then washed 3 times with PBS. Cell nuclei were stained with 4',6-diamidino-2-phenylindole (DAPI) (1:5000, Carlsbad, CA, USA) for $5 \mathrm{~min}$, and washed in PBS for $5 \mathrm{~min}$ at room temperature. Cell images were captured by immunofluorescent microscopy. The cells that appeared with red fluorescence were deemed to be apoptotic.

\section{Total RNA extraction and relative quantitative real time-PCR analysis}

Total RNA was removed from cell cultures with TRIzol reagent (Invitrogen) based on the company's instructions. Extracts were treated with Rnase-free DNase to eliminate any residual genomic DNA. Reverse transcription was performed using a One Step SYBR ${ }^{\circledR}$ PrimeScript $^{\mathrm{TM}}$ PLUS RT-PCR Kit (Takara Bio Inc., Shanghai, China). The oligonucleotide primers used to amplify the target genes were as follows: GAPDH, 5'-AGCCACATCGCTCAGACAC-3' (forward) and 5'-GCCCAATACGACCAAATCC-3' (reverse); interleukin (IL)-1 $\beta, \quad 5^{\prime}$-ATGGGATAACGAGGCTTATGTG-3' (forward) and 5'-CAAGGCCACAGGTATTTTGTC- $3^{\prime}$ (reverse); IL-6, 5'-ACTTGCCTGGTGAAAATCAT-3' (forward) and 5'-CAGGAACTGGATCAGGACTT-3' (reverse); tumor necrosis factor (TNF)- $\alpha, 5^{\prime}$-TCAGCAAGGACAGCAGAGG-3' (forward) and 5'-CAGTATGTGAGAGGAAGAGAACC-3' (reverse); NKCC1: $5^{\prime}$-TGATTCCACTTCCTTTATTGCAG-3' (forward) and $5^{\prime}$-TTAATGAG TTGAGCTCCGGTGA- $3^{\prime}$ (reverse); NF-кB, 5'-TATTTCAACCACAGATGGCACT-3' (forward) and 5'-AGCAAAGGCAATACATACACTT-3' (reverse). All assays were performed 3 times; the results were normalized by GAPDH as an internal control to calculate the $\triangle \mathrm{Ct}$. PCR amplification was done with the parameters: $95{ }^{\circ} \mathrm{C}$ for $40 \mathrm{~s}, 55^{\circ} \mathrm{C}$ for $45 \mathrm{~s}$, and $72{ }^{\circ} \mathrm{C}$ for $50 \mathrm{~s}$. The relative gene expressions were determined with
SDS software (Applied Biosystems, Carlsbad, CA, USA) following 40 cycles.

\section{Extraction of nuclear and cytosolic fractions}

For protein extraction and isolation, a nuclear and cytoplasmic protein extraction kit (Beyotime, Jiangsu, China) was used to separate nuclear and cytoplasmic proteins according to the manufacturer's recommendations. In short, the cells were washed 3 times with PBS after treatment, then scraped, and finally gathered by centrifugation at $1500 \times g$ for $5 \mathrm{~min}$. Cell pellets were lysed on ice for $15 \mathrm{~min}$ with $200 \mathrm{ml}$ extraction buffer A. After, extraction buffer $\mathrm{B}$ was included and samples were vortexed for $30 \mathrm{~s}$ at $4{ }^{\circ} \mathrm{C}$. After the centrifugation of samples at $12,000 \times g$ for $5 \mathrm{~min}$, supernatants were collected and used as cytoplasmic fractions. Pellets were then lysed for $30 \mathrm{~min}$ on ice in $50 \mathrm{ml}$ of nuclear extraction buffer with brief vortexing. After another centrifugation step at $12,000 \times g$ for $5 \mathrm{~min}$, supernatants were collected and used as nuclear fractions.

\section{Western blot analysis}

Proteins were extracted from cell cultures after treatment, and protein concentrations were quantified using a bicinchoninic acid protein assay kit (Pierce Biotechnology, Rockford, IL, USA). Then, $30 \mu \mathrm{g}$ of protein was loaded onto a 6 or $8 \%$ polyacrylamide gel for electrophoresis and then electrotransferred onto a polyvinylidene difluoride membrane (Millipore, Bedford, MA, USA), which was then blocked with $5 \%$ non-fat milk followed by incubation with the appropriate primary antibodies at $4{ }^{\circ} \mathrm{C}$ overnight. Following washing the blots 3 times, the membranes were incubated with HRP-anti-rabbit IgG (HangZhouHuaAn Biotechnology, Zhejiang, China) for $1 \mathrm{~h}$ at room temperature. Immunoreactive proteins were identified via an ECL chemiluminescence system (Pierce Biotechnology). The protein levels were determined by densitometry using Image J1.43 software (National Institutes of Health, Bethesda, MD, USA).

\section{Immunofluorescence}

Astrocytes were seeded in BioFlex ${ }^{\circledR}$ Plates and pretreated with $50 \mu \mathrm{mol} / \mathrm{L}$ ATX or $10 \mu \mathrm{mol} / \mathrm{L}$ PDTC for $2 \mathrm{~h}$ before the induction of injury. Following $24 \mathrm{~h}$ of incubation, the cells were fixed in $4 \%$ paraformaldehyde for $15 \mathrm{~min}$, permeabilized with $0.3 \%$ Triton X-100 solution for $20 \mathrm{~min}$, and then obstructed in $10 \%$ bovine serum albumin for $30 \mathrm{~min}$. Then, the cells were treated overnight at $4{ }^{\circ} \mathrm{C}$ with primary rabbit anti-NKCC1 (1:50) antibody and mouse anti-glial fibrillary acidic protein (1:200). After being washed, the sections were incubated with secondary antibody, Alexa Fluor 488 donkey anti-rabbit IgG (1:500, Invitrogen) and Alexa Fluor 594 donkey anti-mouse IgG 
(1:500, Invitrogen), for $1 \mathrm{~h}$. DAPI (1;5000, Invitrogen) was employed to counterstain the cell nuclei. A Leica confocal laser-scanning microscope (Leica, Wetzlar, Hesse, Germany) was used to acquire confocal microscopic images.

\section{Statistical analysis}

Statistical analyses were performed using GraphPad Prism (version 5.01, GraphPad Software Inc., San Diego, CA, USA). Data are presented as the mean \pm standard error of the mean (SEM) and differences among groups were assessed by one-way analysis of variance followed by the Student-Newman-Keuls test. Statistical significance was set when $\mathrm{p}<0.05$.

\section{Results}

\section{Effects of ATX on astrocyte viability induced by injury}

To determine the influence of injury and positive effect of ATX on injured astrocytes, cells with stretch-induced cell injury were treated with $10,25,50$, or $100 \mu \mathrm{mol} / \mathrm{L}$ of ATX for $24 \mathrm{~h}$. CCK-8 assays were conducted to investigate cell viability. The viability of astrocytes at $1,3,6,12$ and $24 \mathrm{~h}$ after injury was $95.68 \pm 2.72,83.93 \pm 3.68 \%(p<0.05)$, $76.11 \pm 4.43 \%(p<0.01), 70.97 \pm 5.54 \%(p<0.01)$, and $57.90 \pm 5.10 \%(p<0.01)$ of the control values, respectively (Fig. 1a). This suggested that cell viability slowly diminished following injury and $24 \mathrm{~h}$ was selected for the experiments. The viability of cells incubated with ATX at $10,25,50$ and $100 \mu \mathrm{mol} / \mathrm{L}$ for $24 \mathrm{~h}$ was $96.52 \pm 1.69$, $93.28 \pm 2.53,91.55 \pm 2.77$, and $87.04 \pm 2.40 \%(p<0.05)$ compared to the untreated control, respectively (Fig. 1b). The outcomes revealed up to $50 \mu \mathrm{mol} / \mathrm{L}$ of ATX did not have an impact on the viability of the astrocytes and this non-cytotoxic ATX concentration was implemented in every one of the experiments in our study. The decrease in the viability of astrocytes after injury was significantly alleviated by pretreatment with $50 \mu \mathrm{mol} / \mathrm{L}$ of ATX compared with controls (Fig. 1c, $57.90 \pm 5.10 \%$ vs $78.75 \pm 4.43 \%, p<0.05)$. As viewed in Fig. 1d, stretchinduced cell injury triggered vivid morphological changes characteristic of astrocyte damage, while pretreatment with ATX for $2 \mathrm{~h}$ before injury somewhat reduced injuryinduced cytotoxicity and cell damage.

\section{ATX inhibits the apoptotic cell death of astrocytes after injury}

The protein levels of Bax, Bcl-2, cleaved caspase- 3 , and pro-caspase 3 were determined by Western blot analysis to establish if ATX is acted by regulating apoptotic proteins post-injury. Astrocytes were pretreated with ATX $(50 \mu \mathrm{mol} / \mathrm{L})$ and then injured and incubated for another $24 \mathrm{~h}$. As demonstrated in Fig. 2A, Bax expression was significantly increased and $\mathrm{Bcl}-2$ expression was markedly decreased after injury in comparison to the control group $(p<0.01)$, while pretreatment with ATX inhibited
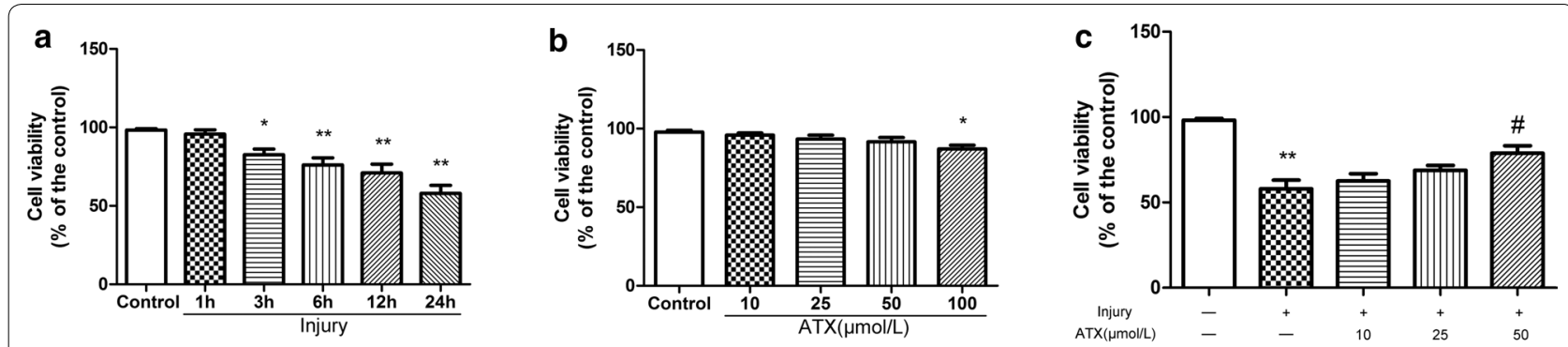

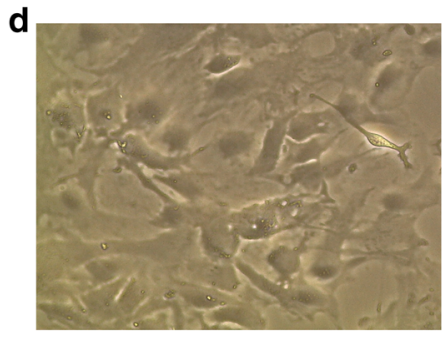

Control

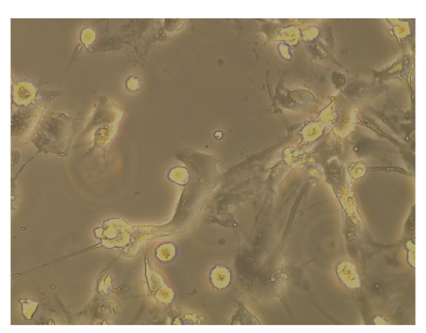

Injury

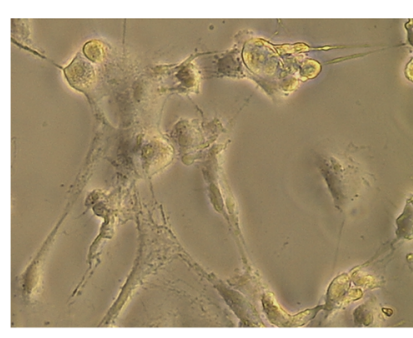

Injury+ATX

Fig. 1 The protective effects of ATX on astrocyte viability after stretch injury. a Astrocytes underwent stretch-induced cell injury. Cell viability at 1 , $3,6,12$, and $24 \mathrm{~h}$ after injury was tested by CCK-8 assays. b Astrocytes were treated with different concentrations of ATX (10, 25,50 or 100 mmol/L) for $24 \mathrm{~h}$. Cell viability was estimated using CCK-8 assays. c Astrocytes were pretreated with 10, 25, or 50 umol/L ATX for $2 \mathrm{~h}$ and then injured and incubated for $24 \mathrm{~h}$. CCK-8 assays were performed to evaluate cell viability. $\mathbf{d}$ Astrocytes were incubated with $50 \mu \mathrm{mol} / \mathrm{L}$ ATX for $2 \mathrm{~h}$ prior to injury for another $24 \mathrm{~h}$, and then morphological changes were analyzed $(\times 200)$. ATX astaxanthin. Mean $\pm \mathrm{SEM}(\mathrm{n}=3)$. ${ }^{*} p<0.05$; ${ }^{* *} p<0.01$ versus the control group; ${ }^{*} p<0.05$ versus the injury group 


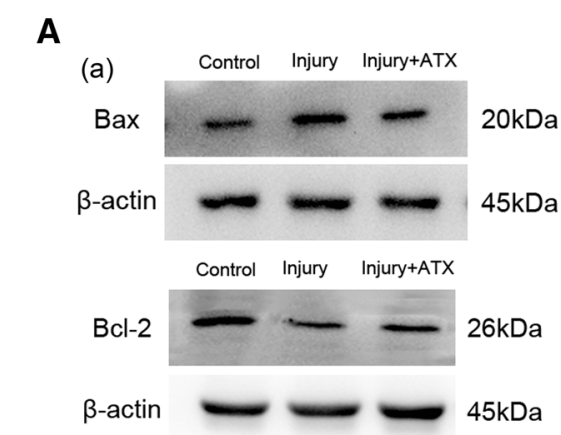

(b)

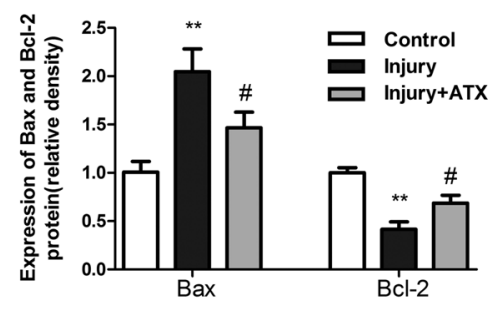

B

(a)

Control Injury Injury+ATX

Cleaved

-caspase3

$\beta$-actin
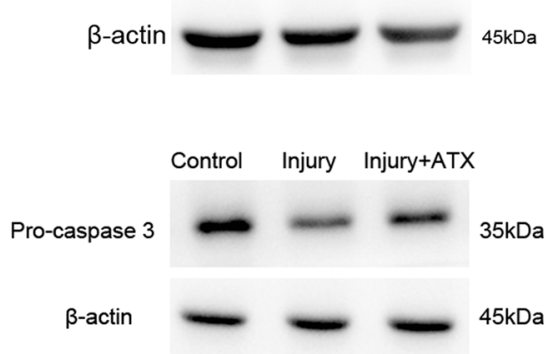

(b)

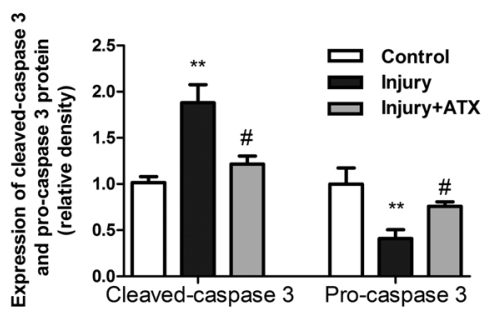

C

(a)
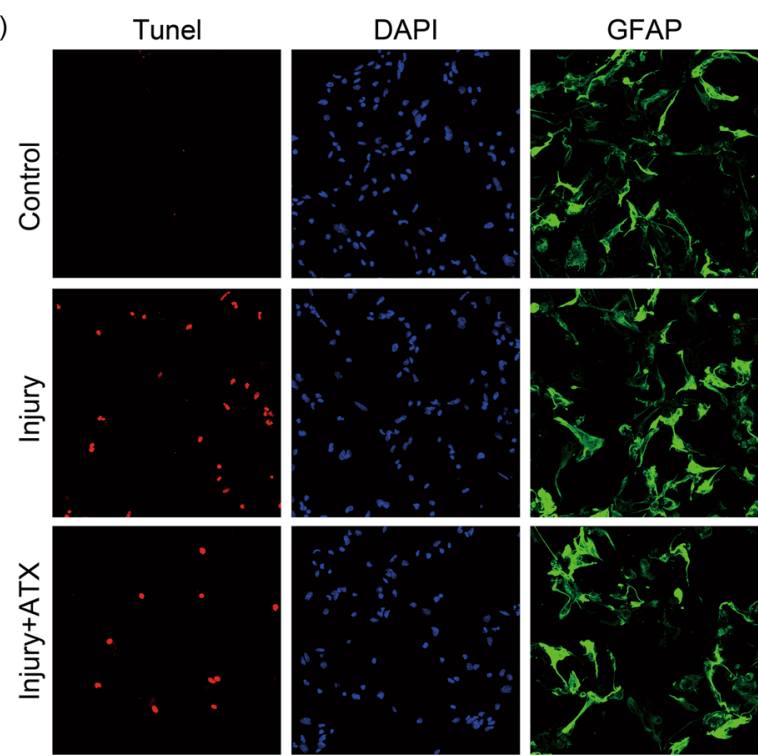

(c)

(c)
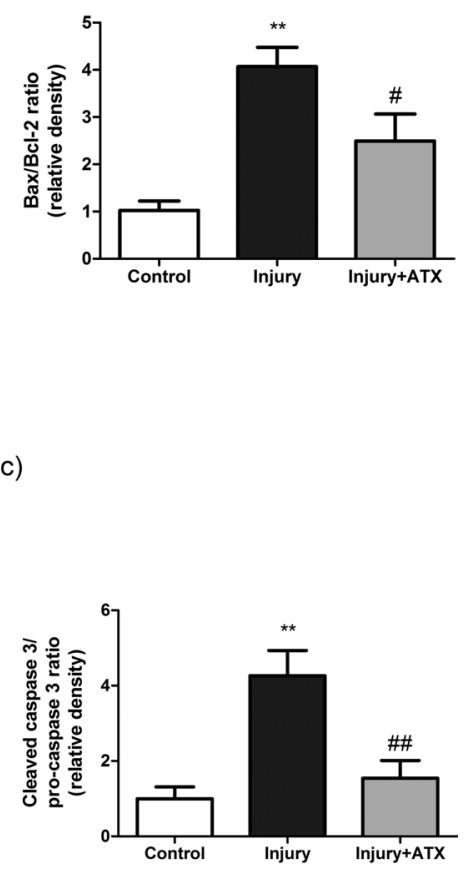

(b)
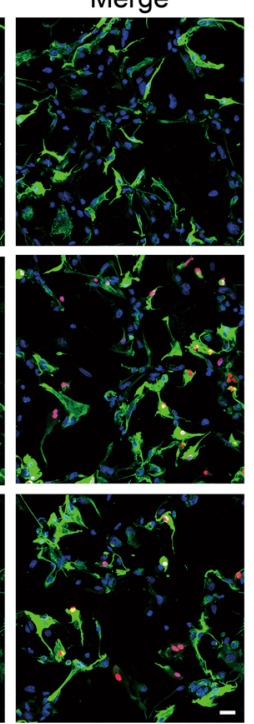

Fig. 2 ATX inhibits the apoptotic cell death of astrocytes after injury. Injury caused a significant increase in the Bax/Bcl-2 ratio (A) and cleaved caspase-3/pro-caspase 3 ratio (B) in astrocytes, which was significantly attenuated by pretreatment with ATX. (C) Representative images of DAPI staining and TUNEL assays used to analyze apoptotic cells (magnification $\times 200$ ). Quantification showed that pretreated with ATX markedly decreased the apoptotic index after injury. Scale bar $25 \mu \mathrm{m}$. ATX astaxanthin. Mean \pm SEM $(n=3)$. ${ }^{* *} p<0.01$ versus the control group; ${ }^{\#} p<0.05$, \#\# $p<0.01$ versus the injury group 
the upregulation of Bax and the downregulation of Bcl-2 $(p<0.05)$. In accordance with the aforementioned findings, cleaved caspase- 3 protein level was strongly induced and pro-caspase 3 protein level was remarkably inhibited after injury compared to the control group $(p<0.01)$, indicating the involvement of caspase- 3 in astrocytes undergoing traumatic cell death (Fig. 2B). However, administration of ATX for $2 \mathrm{~h}$ prior to injury significantly downregulated cleaved caspase- 3 expression and upregulated pro-caspase 3 expression $(p<0.05)$.

Further, the trauma-induced apoptosis of astrocytes was additionally verified via the identification of TUNELpositive staining in situ. As shown in Fig. 2C, the number of apoptotic cells was markedly increased in comparison to untreated cells, and the increased proportion of apoptotic cells was partially attenuated in the ATX-treatment group $(50 \mu \mathrm{mol} / \mathrm{L})$.

These outcomes show ATX successfully obstructs apoptotic cell death post-injury.

\section{Astaxanthin down-regulates the expression of IL-1 $\beta$, IL-6 and TNF- $\alpha$ in astrocytes after injury}

Pro-inflammatory cytokines, which include IL-1 $\beta$, IL-6, and TNF- $\alpha$, are believed to moderate neuroinflammation and cause cell death in different neurodegenerative diseases [24]. Thus, we studied the mRNA and protein expressions of pro-inflammatory factors by qPCR and Western blot analyses after injury. We pretreated astrocytes with ATX $(50 \mu \mathrm{mol} / \mathrm{L})$ for $2 \mathrm{~h}$ and then injured and incubated the cells for $24 \mathrm{~h}$. As shown in Fig. 3, both mRNA expressions and protein levels of IL-1 $\beta$, IL- 6 , and TNF- $\alpha$ were elevated after injury compared with controls $(p<0.01)$. However, the production of pro-inflammatory mediators was significantly reduced by ATX $(p<0.05)$. Furthermore, PDTC $(10 \mu \mathrm{mol} / \mathrm{L})$, an inhibitor of NF- $\mathrm{kB}$, also significantly inhibited the expressions of IL-1 $\beta$, IL- 6 and TNF- $\alpha$ after injury $(p<0.05)$.

\section{Astaxanthin inhibits activation of the NF-кB pathway in astrocytes after injury}

Prior studies have revealed that the initiation of NF-кB controls the expression of inflammatory genes encoding pro-inflammatory cytokines (IL-1 $\beta$, IL- 6 , and TNF- $\alpha$ ) $[25,26]$. Next, we investigate the expression of NF-кB mRNA and protein using qPCR and Western blot analyses at 1, 3, 6, 12, or $24 \mathrm{~h}$ after injury. As shown in Fig. 4A, $\mathrm{B}$, both mRNA expression and protein levels of NF- $\mathrm{KB}$ were increased significantly after $3 \mathrm{~h}(p<0.05$ and $<0.01$, respectively) compared to control cells, with levels peaking at $12 \mathrm{~h}(p<0.01)$ and lasting for $24 \mathrm{~h}(p<0.01)$.

Then, Western blot analysis was performed to investigate the impacts of ATX on the upregulation of NF- $\mathrm{KB}$ proteins in astrocytes post-injury. Cells were pretreated with different concentrations of ATX for $2 \mathrm{~h}$, injured, and then incubated for $24 \mathrm{~h}$. ATX at 25 or $50 \mu \mathrm{mol} / \mathrm{L}$ showed a significant inhibitory effect on the raised expression of NF-kB $(p<0.05$, Fig. 4 C).

Nuclear and cytosolic extracts harvested from astrocytes after injury in the presence or absence of ATX were isolated, and Western blot analysis showed the nuclear translocation of NF-KB was elevated at $24 \mathrm{~h}$ after injury $(p<0.01)$. Pre-incubation with ATX $(50 \mu \mathrm{mol} / \mathrm{L})$ for $2 \mathrm{~h}$ prior to injury significantly decreased the level of NF- $\mathrm{KB}$ protein that translocated into the nucleus $(p<0.05$, Fig. 4D).

\section{Astaxanthin down-regulates NKCC1 expression via the NF-кB pathway in astrocytes after injury}

As shown in Fig. 5A, the NKCC1 mRNA level was elevated at $6 \mathrm{~h}$ after injury $(p<0.05)$, reaching a peak at $12 \mathrm{~h}$ $(p<0.01)$, and lasting for $24 \mathrm{~h}(p<0.05)$. The protein expression of NKCC1 was similar after injury (Fig. 5B). However, pretreatment with ATX $(50 \mu \mathrm{mol} / \mathrm{L})$ or PDTC $(10 \mu \mathrm{mol} / \mathrm{L})$, a NF- $\mathrm{KB}$ inhibitor, significantly reduced the protein expression (Fig. $5 \mathrm{C}, p<0.05$ ).

A comparable effect was observed for NKCC1 expression by immunofluorescence staining (Fig. 5D). NKCC1 expression was significantly increased at $24 \mathrm{~h}$ after injury, while administration of ATX $(50 \mu \mathrm{mol} / \mathrm{L})$ or PDTC $(10 \mu \mathrm{mol} / \mathrm{L})$ decreased its expression compared to the injured group.

\section{Astaxanthin protects against injury-induced astrocyte apoptosis by inactivating the NF-KB/NKCC1 pathway} Last, we explored the possible roles of PDTC and bumetanide (inhibitors of NF-kB and NKCC1, respectively) in apoptosis of astrocytes after injury. The results showed that pretreatment with PDTC $(10 \mu \mathrm{mol} / \mathrm{L})$ and bumetanide $(50 \mu \mathrm{mol} / \mathrm{L})$ for $2 \mathrm{~h}$ significantly inhibited the increase in cleaved caspase- 3 protein expression in astrocytes after injury (Fig. 6).

Altogether, these results suggest that ATX protects astrocytes from apoptotic cell death and these neuroprotective outcomes may be linked to the repression of NF- $\mathrm{KB}$ activation and later diminished activation of NKCC1.

\section{Discussion}

The present study used an in vitro astrocyte stretch injury model to demonstrate that stretch injury directly decreased cell viability, increased apoptotic cell death and NKCC1 expression in cultured astrocytes. Furthermore, ATX, a naturally occurring carotenoid, inhibited these effects in a dose-dependent manner by decreasing the levels of pro-inflammatory cytokines activated by the NF-кB pathway after TBI. To the best of our knowledge, 
A

(a)

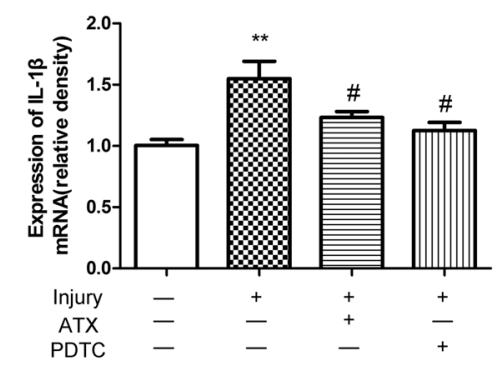

B

(a)

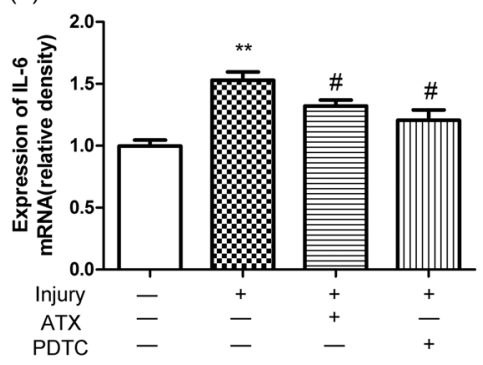

C

(a)

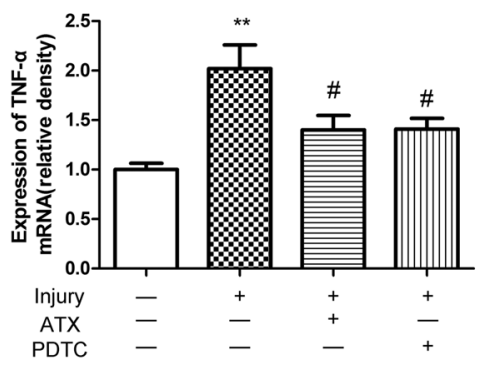

(b)

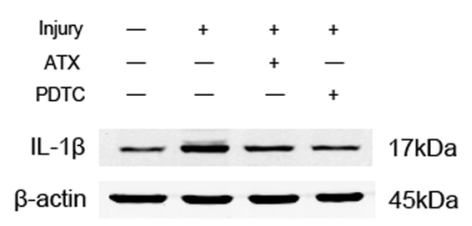

(b)

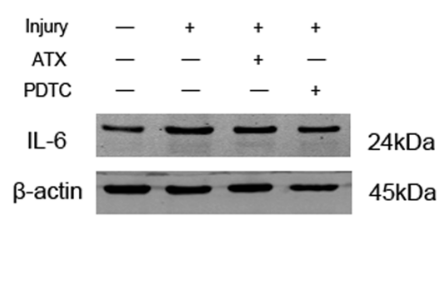

(b)

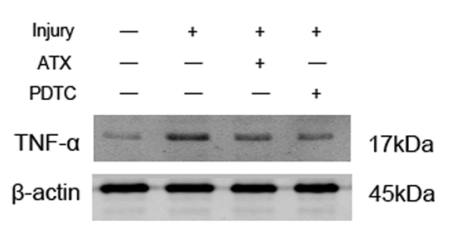

(c)

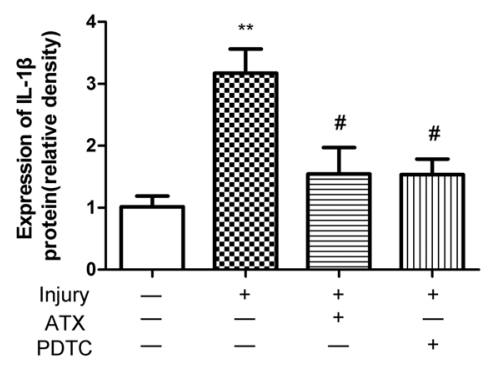

(c)

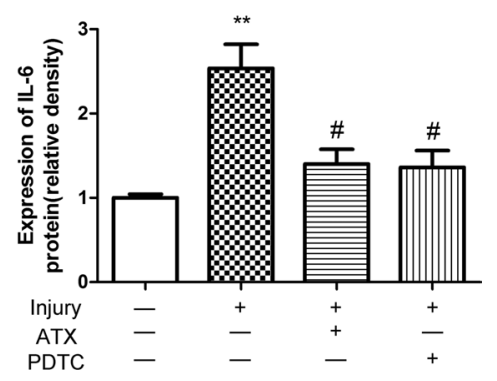

(c)

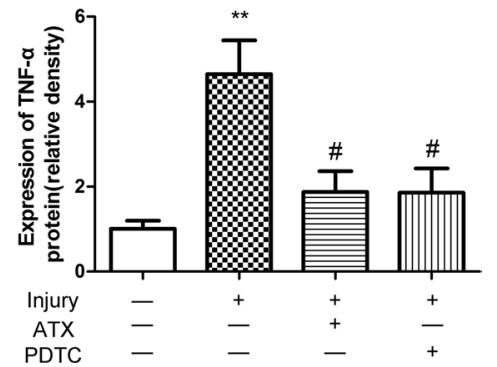

Fig. 3 The effects of ATX on the mRNA and protein expressions of IL-1 $\beta(\mathbf{A}), \mathrm{IL}-6(\mathbf{B})$ and TNF-a $(\mathbf{C})$ in astrocytes after injury. Astrocytes were pretreated with ATX $(50 \mu \mathrm{mol} / \mathrm{L})$ or PDTC $(10 \mu \mathrm{mol} / \mathrm{L})$ for $2 \mathrm{~h}$, injured, and incubated for $24 \mathrm{~h}$. The mRNA expressions of IL-1 $\beta$, IL-6, and TNF-a were elevated after injury compared with controls. However, the production of pro-inflammatory mediators was significantly reduced by ATX or PDTC. GAPDH was used as an internal control. A similar effect was observed for their protein expressions. ATX astaxanthin. Mean \pm SEM ( $n=3$ ). ${ }^{* *}<0.01$ versus the control group; ${ }^{*} p<0.05$ versus the injury group

our results show for the first time, the relationship between ATX and NKCC1, a hallmark of cerebral edema, in an in vitro TBI model and the underlying regulatory mechanisms involved. Thus, ATX may be a novel therapeutic agent for the treatment of TBI.

Brain edema is one of the major consequences of TBI, and astrocyte swelling (cytotoxic edema) represents an important component of brain edema in the early phase [27]. Recent literature reported that in vitro trauma results in cell swelling and a higher susceptibility to cell death in cultured astrocytes [28, 29]. In the present study, the cytoactivity of astrocytes was measured after injury using CCK-8 assays. Cell viability was decreased in a time-dependent manner and reached a minimum at $24 \mathrm{~h}$ following injury. Nevertheless, pretreatment with various concentrations of ATX substantially improved this decrease in cell viability. Likewise, morphological changes that were representative of astrocyte damage were noted post-injury, while pretreatment with ATX somewhat reduced injury-induced cell damage. There exist two important pathways of apoptosis: the extrinsic pathway (receptor-mediated apoptotic pathway) and the intrinsic pathway (mitochondria-mediated apoptotic pathway) with possible cross talk. Numerous studies suggest that trauma-induced cell death transpires via the activation of apoptotic pathways $[29,30]$. The cellular 


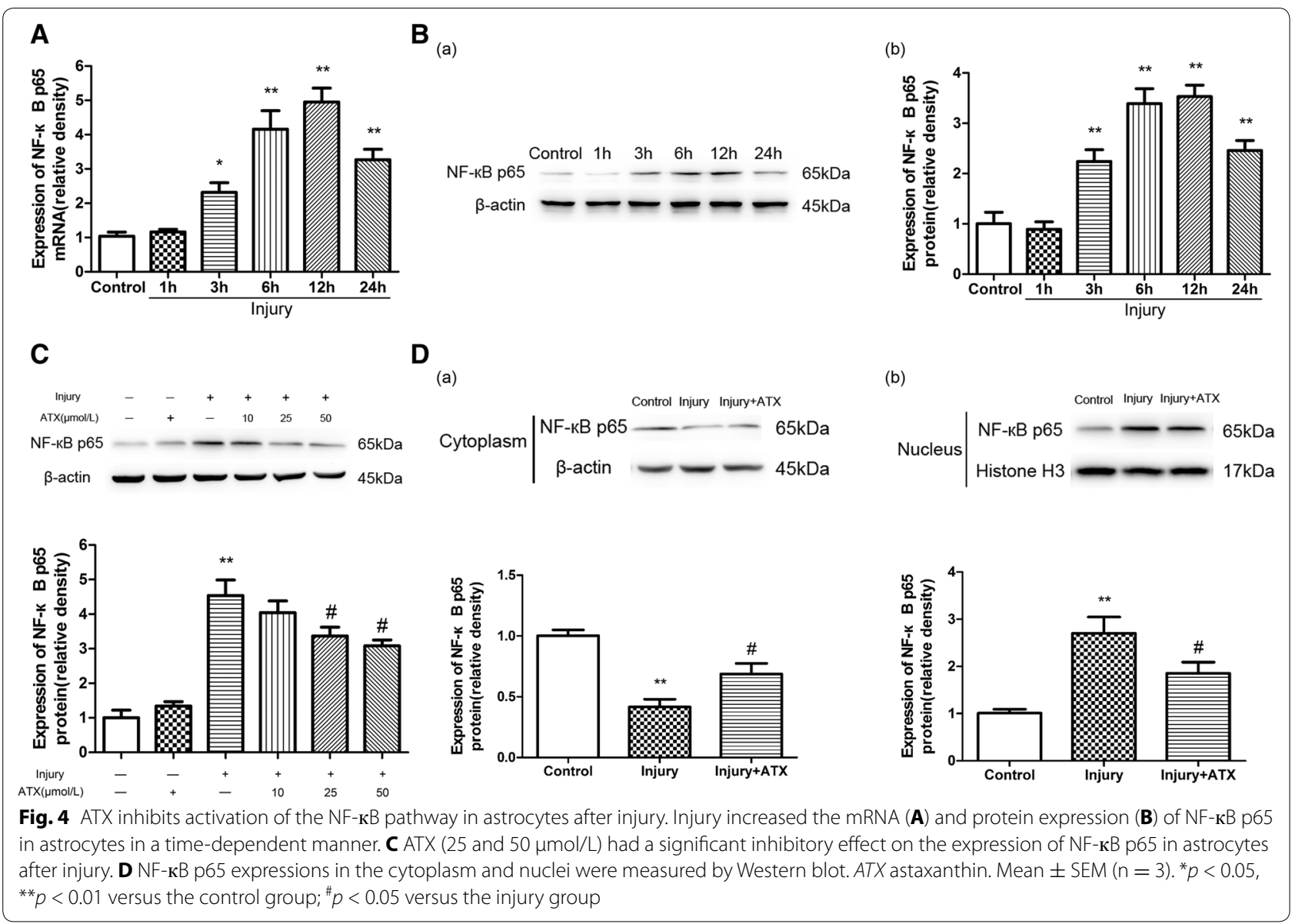

proteins in the innate pathway of apoptosis are part of the Bcl-2 and caspase families. It has been proposed that trauma causes cellular apoptosis by the buildup of Bax and the activation of caspase-3 [30]. Thus, the suppression of pro-apoptotic Bax expression or activated caspase-3 activity and the upregulation of anti-apoptotic Bcl-2 expression could be linked with neuroprotective effects against trauma. In agreement with these outcomes, we showed that trauma led to a rise in the Bax/ Bcl-2 ratio and cleaved caspase-3/pro-caspase 3 ratio in cultured astrocytes. This effect, however, was substantially diminished by ATX, implying that it may protect astrocytes from traumatic injury via the regulation of apoptosis.

Inflammation is linked with astrocyte death and numerous pro-inflammatory mediators, including IL- $1 \beta$, IL-6, and TNF- $\alpha$, could be detrimental to astrocytes [31]. Further, TBI can prompt and inflate inflammatory reactions by their involvement in particular signaling pathways, including the NF-кB pathway [32]. Activation of the NF- $\mathrm{KB}$ pathway can cause a rise in the expression of many genes involved in inflammatory responses, such as cytotoxic cytokines (IL-1 $\beta$, IL-6, and TNF- $\alpha$ ), causing their raised expressions in tissues and direct cytotoxic effects [33]. Therefore, it is necessary to establish if stretch injury changes the expression of cytokine genes and if it is linked with the activation of NF-кB. We showed that mRNA and protein levels of IL- $1 \beta$, IL- 6 , and TNF- $\alpha$ were increased in cultured astrocytes at $24 \mathrm{~h}$ after stretch injury. However, pretreatment with $50 \mu \mathrm{mol} / \mathrm{L}$ ATX reversed the trauma-induced increase of IL-1 $\beta$, IL- 6 , and TNF- $\alpha$ mRNA and protein expressions. A comparable outcome was noted when we implemented PDTC, an inhibitor of NF-KB. This implies that ATX prompts its neuroprotective effects by suppressing proinflammatory cytokines, and these anti-inflammatory outcomes may halt cell death induced by trauma.

NF- $\mathrm{KB}$ consists of a family of transcription factors that positively regulate the expression of genes involved in inflammatory and other responses by binding to their promoters [34, 35]. Typically, the idle form of NF- $\mathrm{KB}$ stays in the cytoplasm as a heterodimer of p50 and p65 subunits. Its activation results in the dissociation and translocation of p65 and p50 subunits to the nucleus, where they up-regulate the transcription of pro-inflammatory genes [36]. We showed that NF-kB expression 


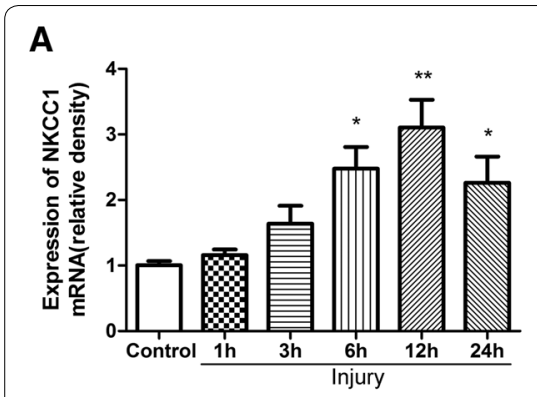

B

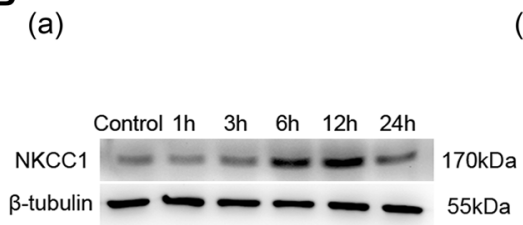

(b)

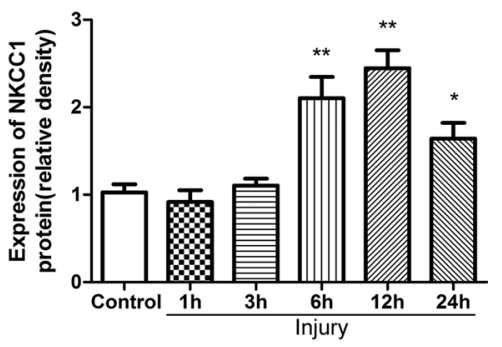

D

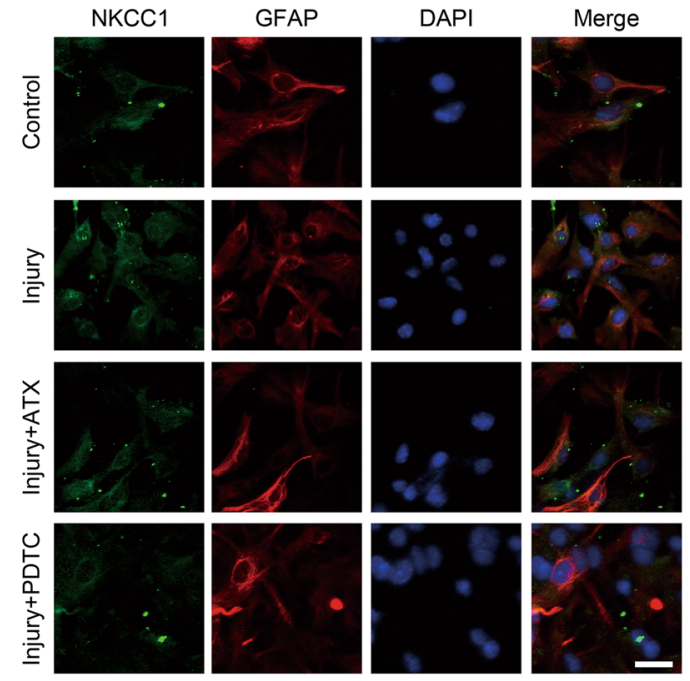

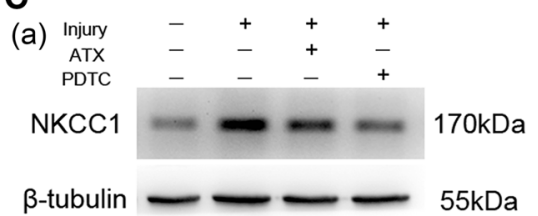

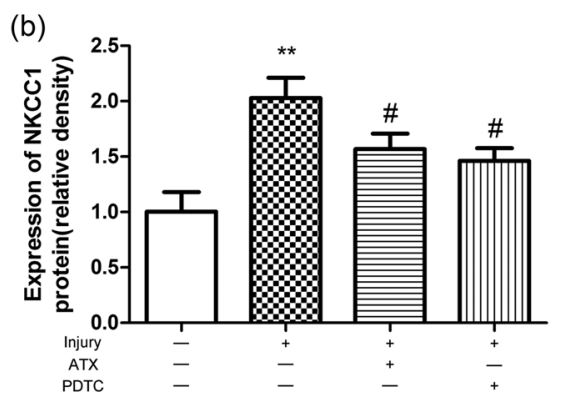

Fig. 5 ATX or PDTC pretreatment inhibits NKCC1 expression in astrocytes after injury. NKCC1 mRNA level (A) and protein expression (B) were elevated in a time-dependent manner after injury. Pretreatment with ATX $(50 \mu \mathrm{mol} / \mathrm{L})$ or PDTC $(10 \mu \mathrm{mol} / \mathrm{L})$ for $2 \mathrm{~h}$ prior to injury reduced NKCC1 protein expression remarkably (C). Immunofluoresence was performed at $24 \mathrm{~h}$ after injury and the fluorescence intensity of NKCC1 in astrocytes was enhanced. Administration of ATX (50 $\mu \mathrm{mol} / \mathrm{L})$ or PDTC $(10 \mu \mathrm{mol} / \mathrm{L})$ for $2 \mathrm{~h}$ prior to injury decreased NKCC1 expression (D). Scale bar $25 \mu \mathrm{m}$. ATX, astaxanthin. Mean $\pm \operatorname{SEM}(n=3) .{ }^{*} p<0.05,{ }^{* *} p<0.01$ versus the control group; ${ }^{*} p<0.05$ versus the injury group was significantly increased after stretch injury in a timedependent manner and that increased levels of NF-кB were consistent with and relevant to the upregulation of IL-1 $\beta$, IL-6, and TNF- $\alpha$. Further, stretch injury prompted $\mathrm{NF}-\mathrm{\kappa B}$ translocation from the cytoplasm to the nucleus; however, ATX substantially prevented raised NF- $k B$ expression and reduced injury-induced NF- $\mathrm{KB}$ translocation into the nucleus. A previous study showed that ATX reduced neuronal apoptosis in the cerebral cortex after subarachnoid hemorrhage by downregulating increased $\mathrm{NF}-\mathrm{kB}$ activity and the expression of inflammatory cytokines [8]. We additionally examined if the prevention of NF- $k B$ activation and translocation to the nucleus are involved in the mechanism of ATX antagonism of injury-induced apoptosis of astrocytes. The increased protein levels of cleaved caspase-3 were notably lowered by pretreatment with ATX and PDTC in astrocytes following stretch injury. Therefore, the activation of NF- $\mathrm{KB}$ could play a critical part in the trauma-induced apoptosis of astrocytes. Furthermore, ATX exhibited neuroprotective effects by inhibiting NF- $\mathrm{kB}$ activation and subsequently decreasing the upregulation of pro-inflammatory cytokines.

NKCC1, a membrane protein that allows the passage of ions and water through the cell membrane, is implicated in the formation of brain edema caused by various injurious insults in vivo, including TBI [14-16]. It was also involved in astrocyte swelling/brain edema in cultured astrocytes after fluid percussion injury [22]. The current study showed that NKCC1 mRNA and protein expression in primary astrocytes were significantly augmented in a time-dependent manner when subjected to stretch injury. However, the administration of $50 \mu \mathrm{mol} / \mathrm{L}$ ATX for $2 \mathrm{~h}$ before injury significantly ameliorated NKCC1 protein levels. This further supports the relationship between $\mathrm{NKCC} 1$ and astrocytes following in vitro trauma and suggests ATX might be a potent inhibitor of NKCC1. Furthermore, NF- $\mathrm{KB}$ activation was strongly implicated 


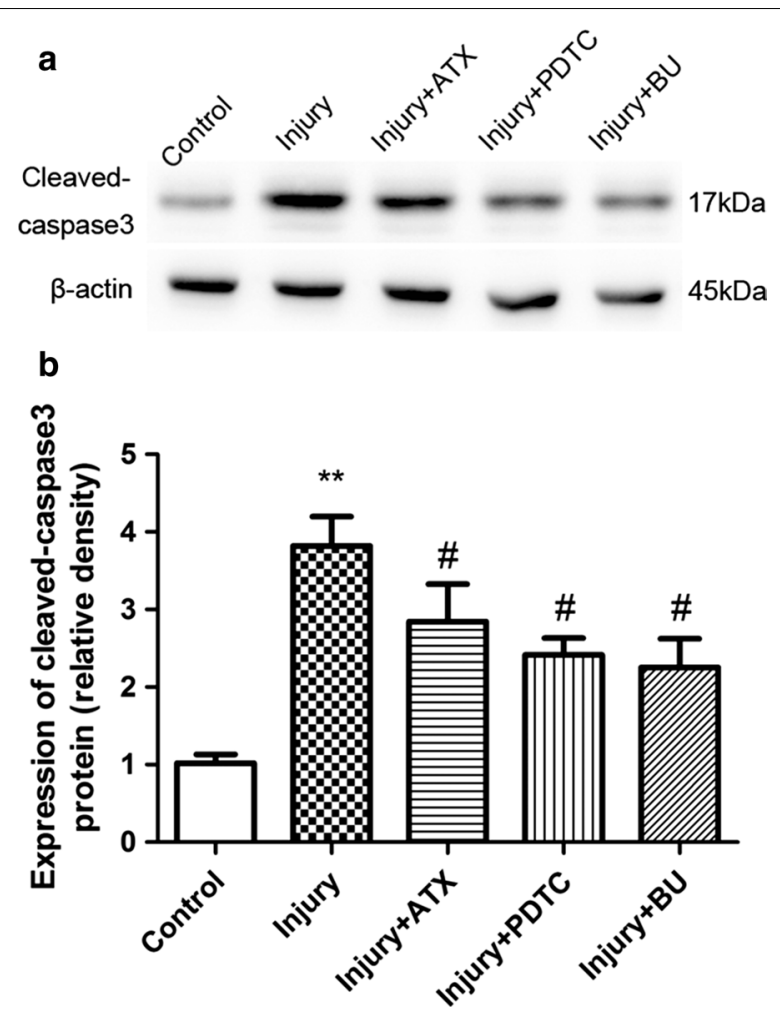

Fig. 6 Neuroprotection by ATX-mediated inhibition of injuryinduced cleaved caspase-3 expression is mediated by NF-KB and NKCC1 inactivation. a Injury significantly increased cleaved caspase-3 protein levels, while pretreatment with ATX ( $50 \mu \mathrm{mol} / \mathrm{L}$ ) for $2 \mathrm{~h}$ significantly downregulated the elevated cleaved caspase-3 protein levels. Similarly, pretreatment with PDTC $(10 \mu \mathrm{mol} / \mathrm{L})$ or bumetanide (BU) $(50 \mu \mathrm{mol} / \mathrm{L})$ for $2 \mathrm{~h}$ prior to injury also markedly inhibited the increase in cleaved caspase-3 protein levels. b Densities of the corresponding bands were measured, and the ratios were calculated. Mean \pm SEM $(n=3) .{ }^{* *} p<0.01$ versus the control group; ${ }^{*} p<0.05$ versus the injury group

in the stimulation of various ion channels/exchangers in different conditions [37-40] and in the regulation of post-traumatic astrocyte swelling/brain edema [3]. Jayakumar et al. [27] reported a significant increase in NKCC activity after trauma to cultured astrocytes, and NF- $\mathrm{KB}$ inhibitor BAY-11 7082 blocked this activity, suggesting NF-кB-mediated cell swelling after trauma is, in part, a consequence of increased NKCC activity. Our data illustrate that $\mathrm{NKCC1}$ expression was associated with increased NF-KB and that PDTC reduced NKCC1 expression. Therefore, ATX might reduce NKCC1 expression through inhibition of the NF-кB pathway. Kim et al. reported that NKCC was a good target for the induction of cell apoptosis by the activation of intracellular $\mathrm{Ca}^{2+}$ signaling and that the NKCC inhibitors, bumetanide and furosemide, markedly suppressed this effect [41]. We further examined whether the inhibition of NKCC1 activation was also involved in the antagonistic effect of
ATX on the apoptosis of astrocytes after stretch injury. Pretreatment with bumetanide $(50 \mu \mathrm{mol} / \mathrm{L})$ significantly downregulated the elevated cleaved caspase- 3 protein level in astrocytes, suggesting ATX reduced the traumainduced apoptosis of astrocytes by inhibiting NKCC1 activation.

In previous study, we demonstrated that ATX might exert neuroprotection by ameliorating NKCC1-mediated cerebral edema after TBI in mice [11]. In this study, we elucidated that ATX prevented NKCC1 expression by limiting NF- $\mathrm{kB}$-mediated pro-inflammatory mediators with an in vitro astrocyte stretch injury model. The discoveries recorded in this research paper, highlighting the anti-inflammatory role of ATX after trauma in cultured astrocytes, is consistent with its application in other diseases [8, 42-44]. Because ATX has other pharmacological properties, such as antioxidative and immunomodulatory properties, future studies should validate these properties in a TBI model. Further, NF- $\mathrm{\kappa B}$ activation is regulated by a broad variety of upstream signals, including MAPKs [45-47], and thus, extensive studies should be performed to explore the explicit mechanisms.

\section{Conclusions}

In summary, our findings indicate that ATX attenuates apoptosis after trauma in cultured astrocytes by inhibiting NKCC1 expression, and that it acts by reducing NF-kB-mediated pro-inflammatory factors. Therefore, ATX is an effective anti-inflammatory agent and might possess therapeutic prospects for TBI treatment.

\section{Abbreviations}

ATX: astaxanthin; CCK-8: Cell Counting Kit-8; DAPI: 4',6-diamidino-2-phenylindole; DMSO: dimethyl sulfoxide; GFAP: glial fibrillary acidic protein; IL: interleukin; NF-кB: nuclear factor kappa B; NKCC: $\mathrm{Na}^{+}-\mathrm{K}^{+}-2 \mathrm{Cl}^{-}$co-transporter; OD: optical density; PBS: phosphate buffered saline; PDTC: pyrrolidine dithiocarbamate; SEM: standard error of the mean; TBI: traumatic brain injury; TUNEL: TdT-dUTP nick-end labeling; WST-8: 2-(2-methoxy-4-nitrophenyl)-3-(4nitrophenyl)-5-(2,4-disulfophenyl)-2H-tetrazolium and monosodium salt.

\section{Authors' contributions}

$\mathrm{MZ}, \mathrm{ZC}$ and $\mathrm{HC}$ carried out all the experiments. YW and $\mathrm{CZ}$ designed the experiments. $M Z, Z C$ and $C Z$ wrote the paper. $Y W$ and $C Z$ directed the study. All authors read and approved the final manuscript.

\section{Author details}

${ }^{1}$ Department of Neurosurgery, Ren Ji Hospital, School of Medicine, Shanghai Jiao Tong University, Shanghai 200127, China. ${ }^{2}$ Department of Neurosurgery, East Hospital, Tongji University School of Medicine, 150 Jimo Road, Shanghai 200120, China. ${ }^{3}$ Department of Neurosurgery, The Affiliated Hospital of Qingdao University, Qingdao 266005, China.

\section{Acknowledgements}

None.

\section{Competing interests}

Professor Chunlong Zhong is an associate editor for BMC Neuroscience. The authors declare that they have no financial and non-financial competing interests. 


\section{Availability of data and materials}

All data are included in the manuscript.

\section{Ethics approval and consent to participate}

All animal procedures were approved by the Institutional Ethics Committee of Renji Hospital, Shanghai Jiao Tong University School of Medicine (RJ-20161020).

\section{Funding}

We received funds from the National Natural Science Foundation of China (Nos. 81571184, 81070990, 30670719, 30500525) and the Shanghai Science and Technology Commission (Nos. 15140902100, 100H1401700) in the process of study design, experiment implementation and data collection. Data interpretation and article writing were supported by the grants from the Shanghai Science and Technology Commission (No. 09140901300) and the Shanghai Municipal Education Commission (No. 09SG20).

\section{Publisher's Note}

Springer Nature remains neutral with regard to jurisdictional claims in published maps and institutional affiliations.

Received: 30 December 2016 Accepted: 26 April 2017

Published online: 10 May 2017

\section{References}

1. Sorani MD, Zador Z, Hurowitz E, Yan D, Giacomini KM, Manley GT. Novel variants in human Aquaporin-4 reduce cellular water permeability. Hum Mol Genet. 2008;17(15):2379-89.

2. Marmarou A. Pathophysiology of traumatic brain edema: current concepts. Acta Neurochir Suppl. 2003:86:7-10.

3. Rao KV, Reddy PV, Curtis KM, Norenberg MD. Aquaporin-4 expression in cultured astrocytes after fluid percussion injury. J Neurotrauma. 2011;28(3):371-81.

4. Fassett RG, Coombes JS. Astaxanthin, oxidative stress, inflammation and cardiovascular disease. Future Cardiol. 2009;5(4):333-42.

5. Chan KC, Mong MC, Yin MC. Antioxidative and anti-inflammatory neuroprotective effects of astaxanthin and canthaxanthin in nerve growth factor differentiated PC12 cells. J Food Sci. 2009;74(7):H225-31.

6. Khan SK, Malinski T, Mason RP, Kubant R, Jacob RF, Fujioka K, Denstaedt SJ, King TJ, Jackson HL, Hieber AD, et al. Novel astaxanthin prodrug (CDX-085) attenuates thrombosis in a mouse model. Thromb Res. 2010;126(4):299-305.

7. Shen H, Kuo CC, Chou J, Delvolve A, Jackson SN, Post J, Woods AS, Hoffer BJ, Wang Y, Harvey BK. Astaxanthin reduces ischemic brain injury in adult rats. FASEB J. 2009;23(6):1958-68

8. Zhang XS, Zhang X, Wu O, Li W, Wang CX, Xie GB, Zhou XM, Shi JX, Zhou ML. Astaxanthin offers neuroprotection and reduces neuroinflammation in experimental subarachnoid hemorrhage. J Surg Res. 2014:192(1):206-13.

9. Zhang XS, Zhang X, Zhou ML, Zhou XM, Li N, Li W, Cong ZX, Sun O Zhuang Z, Wang CX, et al. Amelioration of oxidative stress and protection against early brain injury by astaxanthin after experimental subarachnoid hemorrhage. J Neurosurg. 2014;121(1):42-54

10. Wu Q, Zhang XS, Wang HD, Zhang X, Yu Q, Li W, Zhou ML, Wang XL. Astaxanthin activates nuclear factor erythroid-related factor 2 and the antioxidant responsive element (Nrf2-ARE) pathway in the brain after subarachnoid hemorrhage in rats and attenuates early brain injury. Mar Drugs. 2014;12(12):6125-41

11. Zhang M, Cui Z, Cui H, Cao Y, Zhong C, Wang Y. Astaxanthin alleviates cerebral edema by modulating NKCC 1 and AQP4 expression after traumatic brain injury in mice. BMC Neurosci. 2016;17(1):60.

12. Jayakumar $\mathrm{AR}$, Norenberg MD. The $\mathrm{Na}-\mathrm{K}-\mathrm{Cl}$ co-transporter in astrocyte swelling. Metab Brain Dis. 2010;25(1):31-8.

13. Simard JM, Kahle KT, Gerzanich V. Molecular mechanisms of microvascular failure in central nervous system injury — synergistic roles of NKCC 1 and SUR1/TRPM4. J Neurosurg. 2010;113(3):622-9.

14. Lu KT, Cheng NC, Wu CY, Yang YL. NKCC1-mediated traumatic brain injury-induced brain edema and neuron death via Raf/MEK/MAPK cascade. Crit Care Med. 2008;36(3):917-22.
15. Lu KT, Wu CY, Cheng NC, Wo YY, Yang JT, Yen HH, Yang YL. Inhibition of the $\mathrm{Na}^{+}-\mathrm{K}^{+}-2 \mathrm{Cl}^{-}$-cotransporter in choroid plexus attenuates traumatic brain injury-induced brain edema and neuronal damage. Eur J Pharmacol. 2006;548(1-3):99-105.

16. Lu KT, Wu CY, Yen HH, Peng JH, Wang CL, Yang YL. Bumetanide administration attenuated traumatic brain injury through IL-1 overexpression. Neurol Res. 2007:29(4):404-9.

17. Yan $Y$, Dempsey RJ, Sun D. $\mathrm{Na}^{+}-\mathrm{K}^{+}-\mathrm{Cl}^{-}$cotransporter in rat focal cerebral ischemia. J Cereb Blood Flow Metab. 2001;21(6):711-21.

18. Chen H, Luo J, Kintner DB, Shull GE, Sun D. Na ${ }^{+}$-dependent chloride transporter (NKCC1)-null mice exhibit less gray and white matter damage after focal cerebral ischemia. J Cereb Blood Flow Metab. 2005;25(1):54-66.

19. Simard JM, Chen M, Tarasov KV, Bhatta S, Ivanova S, Melnitchenko L, Tsymbalyuk N, West GA, Gerzanich V. Newly expressed SUR1-regulated NC(Ca-ATP) channel mediates cerebral edema after ischemic stroke. Nat Med. 2006:12(4):433-40.

20. Conti L, Palma E, Roseti C, Lauro C, Cipriani R, de Groot M, Aronica E, Limatola C. Anomalous levels of $\mathrm{Cl}^{-}$transporters cause a decrease of GABAergic inhibition in human peritumoral epileptic cortex. Epilepsia. 2011:52(9):1635-44.

21. Haas BR, Sontheimer H. Inhibition of the sodium-potassium-chloride Cotransporter Isoform-1 reduces glioma invasion. Cancer Res. 2010;70(13):5597-606.

22. Jayakumar AR, Panickar KS, Curtis KM, Tong XY, Moriyama M, Norenberg MD. Na-K-Cl cotransporter-1 in the mechanism of cell swelling in cultured astrocytes after fluid percussion injury. J Neurochem. 2011;117(3):437-48

23. Ellis EF, McKinney JS, Willoughby KA, Liang S, Povlishock JT. A new model for rapid stretch-induced injury of cells in culture: characterization of the model using astrocytes. J Neurotrauma. 1995;12(3):325-39.

24. Cui ZW, Xie ZX, Wang BF, Zhong ZH, Chen XY, Sun YH, Sun QF, Yang GY, Bian LG. Carvacrol protects neuroblastoma SH-SY5Y cells against $\mathrm{Fe}^{2+}$-induced apoptosis by suppressing activation of MAPK/JNK-NFkappaB signaling pathway. Acta Pharmacol Sin. 2015;36(12):1426-36.

25. Cuzzocrea S, Chatterjee PK, Mazzon E, Dugo L, Serraino I, Britti D, Mazzullo G, Caputi AP, Thiemermann C. Pyrrolidine dithiocarbamate attenuates the development of acute and chronic inflammation. Br J Pharmacol. 2002:135(2):496-510.

26. Sehnert B, Burkhardt H, Wessels JT, Schroder A, May MJ, Vestweber D, Zwerina J, Warnatz K, Nimmerjahn F, Schett G, et al. NF-kappaB inhibitor targeted to activated endothelium demonstrates a critical role of endothelial NF-kappaB in immune-mediated diseases. Proc Natl Acad Sci USA. 2013;110(41):16556-61.

27. Jayakumar AR, Tong XY, Ruiz-Cordero R, Bregy A, Bethea JR, Bramlett $H M$, Norenberg MD. Activation of NF-kappaB mediates astrocyte swelling and brain edema in traumatic brain injury. J Neurotrauma. 2014:31(14):1249-57.

28. Jayakumar AR, Rao KV, Panickar KS, Moriyama M, Reddy PV, Norenberg MD. Trauma-induced cell swelling in cultured astrocytes. J Neuropathol Exp Neurol. 2008;67(5):417-27.

29. Raghupathi R. Cell death mechanisms following traumatic brain injury. Brain Pathol. 2004;14(2):215-22.

30. Raghupathi R, Graham DI, McIntosh TK. Apoptosis after traumatic brain injury. J Neurotrauma. 2000;17(10):927-38.

31. Jensen CJ, Massie A, De Keyser J. Immune players in the CNS: the astrocyte. J Neuroimmune Pharmacol. 2013;8(4):824-39.

32. Harvey LD, Yin Y, Attarwala IY, Begum G, Deng J, Yan HQ, Dixon CE, Sun D. Administration of DHA Reduces endoplasmic reticulum stress-associated inflammation and alters microglial or macrophage activation in traumatic brain injury. ASN Neuro 2015; 7(6). doi:10.1177/1759091415618969.

33. Barnes PJ, Karin M. Nuclear factor-kappaB: a pivotal transcription factor in chronic inflammatory diseases. N Engl J Med. 1997;336(15):1066-71.

34. Karin M, Greten FR. NF-kappaB: linking inflammation and immunity to cancer development and progression. Nat Rev Immunol. 2005;5(10):749-59.

35. Courtois G, Gilmore TD. Mutations in the NF-kappaB signaling pathway: implications for human disease. Oncogene. 2006;25(51):6831-43.

36. Lee J, Kim YS, Choi DH, Bang MS, Han TR, Joh TH, Kim SY. Transglutaminase 2 induces nuclear factor-kappaB activation via a novel pathway in BV-2 microglia. J Biol Chem. 2004;279(51):53725-35. 
37. Sirabella R, Secondo A, Pannaccione A, Scorziello A, Valsecchi V, Adornetto A, Bilo L, Di Renzo G, Annunziato L. Anoxia-induced NF-kappaBdependent upregulation of $\mathrm{NCX} 1$ contributes to $\mathrm{Ca}^{2+}$ refilling into endoplasmic reticulum in cortical neurons. Stroke. 2009;40(3):922-9.

38. Valsecchi V, Pignataro G, Sirabella R, Matrone C, Boscia F, Scorziello A, Sisalli MJ, Esposito E, Zambrano N, Cataldi M, et al. Transcriptional regulation of ncx1 gene in the brain. Adv Exp Med Biol. 2013;961:137-45.

39. Sathish V, Delmotte PF, Thompson MA, Pabelick CM, Sieck GC, Prakash YS. Sodium-calcium exchange in intracellular calcium handling of human airway smooth muscle. PLoS ONE. 2011;6(8):e23662.

40. Yu Y, Keller SH, Remillard CV, Safrina O, Nicholson A, Zhang SL, Jiang W, Vangala N, Landsberg JW, Wang JY, et al. A functional single-nucleotide polymorphism in the TRPC6 gene promoter associated with idiopathic pulmonary arterial hypertension. Circulation. 2009;119(17):2313-22.

41. Kim JA, Kang YY, Lee YS. Activation of $\mathrm{Na}^{+}, \mathrm{K}^{+}, \mathrm{Cl}^{-}$-cotransport mediates intracellular $\mathrm{Ca}^{2+}$ increase and apoptosis induced by Pinacidil in HepG2 human hepatoblastoma cells. Biochem Biophys Res Commun. 2001;281(2):511-9.

42. Lee SJ, Bai SK, Lee KS, Namkoong S, Na HJ, Ha KS, Han JA, Yim SV, Chang $\mathrm{K}$, Kwon YG, et al. Astaxanthin inhibits nitric oxide production and inflammatory gene expression by suppressing I(kappa)B kinase-dependent NF-kappaB activation. Mol Cells. 2003;16(1):97-105.
43. Franceschelli S, Pesce M, Ferrone A, De Lutiis MA, Patruno A, Grilli A, Felaco M, Speranza L. Astaxanthin treatment confers protection against oxidative stress in U937 cells stimulated with lipopolysaccharide reducing $\mathrm{O}^{2-}$ production. PLoS ONE. 2014;9(2):e88359.

44. Speranza L, Pesce M, Patruno A, Franceschelli S, de Lutiis MA, Grilli A, Felaco M. Astaxanthin treatment reduced oxidative induced pro-inflammatory cytokines secretion in U937: SHP-1 as a novel biological target. Mar Drugs. 2012;10(4):890-9.

45. Borsello T, Forloni G. JNK signalling: a possible target to prevent neurodegeneration. Curr Pharm Des. 2007;13(18):1875-86.

46. Xing B, Liu M, Bing G. Neuroprotection with pioglitazone against LPS insult on dopaminergic neurons may be associated with its inhibition of NF-kappaB and JNK activation and suppression of COX-2 activity. J Neuroimmunol. 2007;192(1-2):89-98.

47. Youdim MB, Grunblatt E, Mandel S. The pivotal role of iron in NF-kappa B activation and nigrostriatal dopaminergic neurodegeneration. Prospects for neuroprotection in Parkinson's disease with iron chelators. Ann N Y Acad Sci. 1999:890:7-25.

\section{Submit your next manuscript to BioMed Central and we will help you at every step:}

- We accept pre-submission inquiries

- Our selector tool helps you to find the most relevant journal

- We provide round the clock customer support

- Convenient online submission

- Thorough peer review

- Inclusion in PubMed and all major indexing services

- Maximum visibility for your research

Submit your manuscript at www.biomedcentral.com/submit
() Biomed Central 